\title{
Identifikasi Perjanjian Internasional Global dan Regional Tentang Perlindungan Flora dan Fauna
}

\author{
Andreas Pramudianto $^{1 *}$ \\ ${ }^{1}$ Universitas Indonesia, Sekolah Ilmu Lingkungan, Jl. Salemba Raya No. 4, Jakarta Pusat 10430, \\ Indonesia
}

\section{Kata Kunci: \\ Perjanjian \\ internasional global \\ dan regional, flora \\ dan fauna, soft law \\ dan hard law, \\ komersial dan non- \\ komersial}

\begin{abstract}
Abstrak
Perjanjian Internasional yang melindungi flora dan fauna telah berkembang sejak lama. Banyaknya perjanjian internasional tersebut baik berupa convention, agreement, protocol dan bentuk lainnya baik yang hard law maupun soft law telah menunjukan bahwa masyarakat internasional tetap peduli pada perlindungan flora dan fauna. Penelitian ini bertujuan untuk menggambarkan secara umum berbagai perjanjian internasional baik soft law maupun hard law yang telah berkembang selama ini baik di tingkat global maupun regional. Tujuan penelitian ini adalah untuk mengidentifikasi berbagai bentuk perjanjian internasional terutama yang berkaitan dengan perlindungan flora dan fauna. Penelitian ini menggunakan metode deskriptif analitis kualitatif dengan pendekatan norma hukum agar sesuai dengan tujuan penelitian. Hasil penelitian menunjukan bahwa perjanjian internasional untuk melindungi flora dan fauna sudah dikembangkan baik di tingkat global maupun regional. Namun tujuan dan motif dari perlindungan tersebut ternyata memiliki kepentingan yang bermacam-macam terutama baik yang bersifat komersial maupun nonkomersial.
\end{abstract}

Keywords:

Abstract

Global and regional international agreements, flora and fauna, soft law and hard law, commercial and non-commercial
International agreements that protect flora and fauna have evolved a long time ago. The number of international agreements in the form of conventions, agreements, protocols and other forms of both hard and soft law has shown that the international community still cares about the protection of flora and fauna. This research aim to describe in general the various international agreements both soft law and hard law that have developed so far both at the global and regional levels. The purpose of this study is to identify various forms of international treaties, especially those relating to the protection of flora and fauna. This study uses descriptive qualitative analytical methods with a legal norm approach to match the research objectives. The results show that international agreements to protect flora and fauna have been developed both globally and regionally. However, the purpose and motive of the protection turned out to have a variety of interests, especially both commercial and non-commercial.

\footnotetext{
*Penulis koresponden: andreas.pramudianto@gmail.com
} 


\section{PENDAHULUAN}

\subsection{Latar Belakang}

Perburuan terhadap flora maupun fauna oleh manusia sudah dilakukan sejak zaman dahulu kala. Pada awalnya perburuan ini dilakukan untuk memenuhi kebutuhan seharihari seperti makanan, pakaian, rumah tinggal. Namun di era modern sekarang ini perburuan baik terhadap flora maupun fauna lebih kepada pemenuhan rasa kesenangan seperti hobi maupun komersial. Banyak jenis spesies flora tertentu seperti anggrek dan tanaman keras seperti pohon jati agar dapat diperdagangkan karena laku keras di pasaran. Sementara itu jenis satwa seperti beberapa jenis burung, ular, buaya bahkan satwa besar seperti harimau, badak, maupun satwa di laut seperti penyu dan beberapa jenis ikan seperti tuna hingga mamalia paus banyak diburu baik untuk hobi maupun untuk diperdagangkan. Tentu saja flora dan fauna jenis-jenis yang menarik untuk berbagai macam kebutuhan manusia semakin lama semakin sedikit jumlahnya, bahkan ada juga yang sudah punah.

Terhadap jenis flora dan fauna ini, ternyata oleh manusia dinilai sangat mahal terutama dari segi ekonomi. Nilai jual inilah yang menyebabkan jenis-jenis flora dan fauna tersebut banyak diburu di alam yang kemudian diambil atau ditangkap untuk diperjual belikan. Jika jumlah pengambilan atau tangkapan terbatas, barangkali tidak menimbulkan masalah, namun jika jumlahnya sangat banyak dan tidak terkendali, tentu saja akan mengakibatkan jumlah spesies tersebut semakin langka bahkan dapat mencapai kepunahan. IUCN telah mempublikasikan daftar spesies yang dikategorikan mulai dari jarang hingga punah melalui IUCN Red Data List (IUCN 2019). Contohnya tanaman seperti kantung semar seperti jenis nepenthes fusca (Clarke 2018) yang masuk daftar dalam keadaan rentan (vurnerable/V) dan nepenthes rigidifolia (Clarke 2014) dalam keadaan kritis (critical/CR).

Upaya perlindungan terhadap flora dan fauna sudah dilakukan diantaranya melalui perjanjian internasional. Bernie dan Boyle (1992) menyebutkan sudah ada perjanjian internasional untuk melindungi mamalia paus di tahun 1597 walaupun bersifat bilateral. Pendekatan perlindungan saat itu adalah untuk melindungi dan memanfaatkan sumber daya alam yang ada. Selain itu faktor kepentingan ekonomi, status sosial, hak kepemilikan, pengaturan perburuan, komersialisasi, kekuasaan dan tindakan-tindakan lain yang menganggap persediaan yang berlimpah, ternyata masih mendominasi pemikiran diatas (Pramudianto 2004).

Perubahan paradigma diawali menjelang tahun 1948 ketika didirikannya International Union for Conservation of Nature (IUCN) atau Uni Internasional untuk Perlindungan Alam. Didirikannya IUCN yang menjadi lembaga internasional yang berupaya melindungi alam dimana flora dan fauna berada, telah membawa pengaruh bagi meningkatnya kesadaran masyarakat internasional terhadap flora dan fauna dan terbentuknya beberapa perjanjian internasional. Pada tahun 1949, dengan dipelopori oleh United Nations Educational, Scientific and Cultural Organization (UNESCO) dan dukungan IUCN diadakan pertemuan internasional mengenai pengelolaan sumberdaya alam dimana perlindungan flora dan fauna menjadi bagian dalam pertemuan ini. Lahirnya Deklarasi Stockhlom 1972 dan Deklarasi Rio 1992 yang telah memperkenalkan konsep pembangunan berkelanjutan (sustainable development) mulai mengubah orientasi dari hanya memikirkan generasi sekarang menuju generasi mendatang. Penggunaan pembangunan berkelanjutan demi masa depan generasi sekarang maupun mendatang mulai dipakai dalam berbagai perjanjian internasional. Konsep ini juga mendasari filosofi berbagai perjanjian internasional selanjutnya dalam kerangka perlindungan flora dan fauna di masa mendatang.

Namun permasalahan pokoknya adalah tujuan dan motif perlindungan flora dan fauna dalam prakteknya hingga saat ini masih dipengaruhi oleh pertarungan antara kepentingan konservasi dengan kepentingan komersial. Tentu saja hal ini juga akan mempengaruhi perkembangan dari perjanjian internasional yang dibentuk dan keberpihakan masyarakat internasional terhadap perlindungan flora dan fauna di tingkat global maupun regional.

Identifikasi permasalahan yang dapat dikemukakan dalam penelitian ini adalah: (a) Apakah perjanjian internasional yang mengatur perlindungan flora dan fauna masih berfokus pada komersialisasi? (b) Bagaimana bentuk 
perjanjian internasional yang berperan dalam menangani perlindungan flora dan fauna? (c) Bagaimana perjanjian internasional yang mampu memberikan perlindungan flora dan fauna dibentuk dalam tingkat global maupun regional?

Maksud penelitian ini adalah untuk memahami dan menganalisis perkembangan perjanjian internasional terkait dengan perlindungan flora dan fauna. Sedangkan tujuan dari penelitian ini adalah: (a) Mengidentifikasi perjanjian internasional yang berhubungan dengan perlindungan flora dan fauna. (b) Mengetahui dan mendeskripsikan perjanjian internasional yang berhubungan dengan flora dan fauna. (c) Menganalisis kategori perjanjian internasional yang berhubungan dengan flora dan fauna terkait dengan perlindungan dan komersialisasi. Adapun ruang lingkup penelitian ini adalah mengkaji perjanjian internasional yang berhubungan dengan perlindungan flora dan fauna baik di tingkat global maupun regional.

Adapun manfaat penelitian adalah: (a) Memberikan informasi dasar untuk menambah kajian atau studi mengenai perjanjian internasional yang berhubungan dengan perlindungan flora dan fauna. (b) Secara ilmiah penelitian ini akan bermanfaat bagi pengembangan ilmu hukum, khususnya hukum lingkungan internasional terutama perjanjian internasional yang berhubungan dengan perlindungan flora dan fauna. (c) Bagi pengambil keputusan, penelitian ini akan bermanfaat untuk menentukan apakah suatu perjanjian internasional mampu melindungi flora dan fauna baik dari aspek komersial maupun non-komersial.

\subsection{Studi Pustaka}

Pasal 2 bagian 1 butir a Vienna Convention on the Law of Treaties 1969 atau Konvensi Wina mengenai Hukum Perjanjian tahun 1969 mendefinisikan perjanjian internasional adalah kesepakatan antarnegara dalam bentuk tertulis yang diatur berdasarkan hukum internasional baik berbentuk instrumen tunggal maupun lebih dan apapun bentuk rancangannya. Dalam teks konvensi tersebut dinyatakan "”treaty" means an international agreement concluded between States in written form and governed by international law, whether embodied in a single instrument or in two or more related instruments and whatever its particular designation."

Menurut Kusumaatmadja (1976), Starke (1996), Mauna (2008), Parthiana (2005), Suryokusumo (2008), (Agusman 2010), (Pratomo 2011) dan Pramudianto (2014) perjanjian internasional dapat dilihat dalam berbagai sudut pandang seperti perjanjian internasional ditinjau dari jumlah negaranegara yang menjadi pihak atau pesertanya terdiri atas (i) Perjanjian internasional bilateral dan (ii) Perjanjian internasional multilateral. Sedangkan perjanjian internasional ditinjau dari kaidah hukumnya terdiri atas (i) perjanjian internasional yang melahirkan kaidah hukum yang khusus, (ii) perjanjian internasional yang melahirkan kaidah hukum yang berlaku terbatas dalam suatu kawasan dan (iii) perjanjian internasional yang melahirkan kaidah hukum yang berlaku umum. Perjanjian internasional dapat juga ditinjau dari segi kesempatan yang diberikan kepada negaranegara untuk menjadi pihak atau peserta, dapat terdiri atas (i) perjanjian internasional khusus, atau perjanjian internasional tertutup dan (ii) perjanjian internasional terbuka.

Perjanjian internasional dapat ditinjau dari segi bahasanya terdiri atas (i) perjanjian internasional yang dirumuskan dalam satu bahasa, (ii) perjanjian internasional yang dirumuskan dalam dua bahasa atau lebih tetapi hanya dirumuskan dalam satu bahasa tertentu saja yang sah serta mengikat para pihak dan (iii) perjanjian internasional yang dirumuskan dalam lebih dari dua bahasa atau lebih dan semuanya merupakan naskah yang sah, otentik, dan mempunyai kekuatan mengikat yang sama.

Perjanjian internasional jika ditinjau dari segi substansi hukum yang dikandungnya terdiri atas (i) perjanjian internasional yang seluruh pasalnya merupakan perumusan dari kaidah-kaidah hukum kebiasaan internasional dalam bidang yang bersangkutan, (ii) perjanjian internasional yang merupakan perumusan atau yang melahirkan kaidahkaidah hukum internasional yang sama sekali baru, dan (iii) perjanjian internasional yang substansinya merupakan perpaduan antara kaidah-kaidah hukum kebiasaan internasional yang baru sama sekali.

Jika ditinjau dari tahapan pembuatan perjanjian dapat dibagi menjadi dua, yaitu (i) pembuatan perjanjian internasional yang melalui dua tahap dan (ii) pembuatan perjanjian internasional melalui tiga tahap. 
Untuk perjanjian internasional yang dilakukan melalui 2 (dua) tahap terbagi dalam (i) tahap perundingan (negotiation) dan (ii) tahap penandatanganan (signature). Tahap terakhir dalam pembentukan perjanjian melalui dua tahap ini mempunyai makna sebagai pengikatan diri dari para pihak terhadap naskah perjanjian yang telah disepakati. Sedangkan perjanjian internasional melalui 3 (tiga) tahap terdiri dari (i) tahap perundingan, (ii) tahap penandatanganan, dan (iii) tahap pengesahan (ratification). Agar perjanjian yang telah ditandatangani oleh wakil-wakil para pihak tersebut mengikat bagi para pihak maka wakilwakil para pihak tersebut harus mengajukan kepada pemerintah negaranya masing-masing untuk disahkan atau diratifikasi.

Selain dari berbagai sudut pandang, perjanjian internasional juga dapat dilihat dari berbagai bentuk perjanjian internasional. Bentuk ini bermacam-macam namun dalam kajian ini akan dilihat yang umum disebutkan dalam perjanjian internasional terkait perlindungan flora dan fauna. Adapun perjanjian internasional tersebut, Parthiana (2002), Suryokusumo (2008), Agusman (2010), (Pratomo 2011), dan (Pramudianto 2014), diantaranya:

(a) Traktat (Treaty). Biasanya digunakan dalam perjanjian multilateral baik yang bersifat terbuka atau terbatas. Contoh adalah International Treaty on Plant Genetic Resources for Food and Agriculture tahun 2001.

(b) Piagam (Charter). Piagam atau charter biasanya diberikan kepada perjanjian internasional yang membentuk suatu organisasi internasional ataupun lembaga tertentu. Sebagai contoh adalah Piagam Pembentukan International Union for Conservation of Nature (IUCN). Akan tetapi hal ini tidak bisa konsisten karena dapat merupakan bentuk soft law yang non legally binding dan bukan sebagai hard law yang bersifat mengikat secara hukum (legally binding). Sebagai contoh adalah Piagam Dunia untuk Alam atau World Charter for Nature yang kemudian diperkuat menjadi Resolusi Majelis Umum PBB Nomor A/RES/37/7. Contoh lainnya adalah Piagam Bumi 1992 (Earth Charter 1992) yang disepakati oleh beberapa negara, NGO dan organisasi internasional pada waktu KTT Bumi 1992 di Rio De Janeiro, Brasil.

(c) Konvensi (Convention). Konvensi banyak digunakan dalam perjanjian internasional untuk perlindungan flora dan fauna. Bentuk ini sangat populer dan banyak mengatur hal-hal yang penting dan prinsip. Sebagai contoh adalah Convention on International Trade in Endangered Species of Wild Fauna and Flora (CITES) yang ditandatangani tahun 1973.

(d) Protokol (Protocol). Penggunaan protokol (protocol) umumnya dipakai sebagai pelengkap konvensi atau instrumen tambahan yang bersifat independen dari suatu konvensi. Sebagai contoh adalah Cartagena Protocol on Biosafety to the Convention on Biological Diversity tahun 2000.

(e) Pengaturan (Arrangements). Bentuk ini jarang digunakan dan umumnya mengatur hal-hal yang bersifat khusus. Sebagai contoh adalah Arrangements for the Regulation of Antartic Pelagic Whaling yang ditandatangani pada tanggal 6 Juni tahun 1962.

(f) Persetujuan (Agreement). Merupakan bentuk yang biasanya mengatur hal tertentu secara khusus. Sebagai contoh adalah Agreement on the Conservation of Polar Bears yang ditandatangani pada tanggal 15 November tahun 1973 di kota Oslo.

(g) Tindakan (Act). Beberapa perjanjian internasional memakai istilah ini yang umumnya bersifat sangat teknis dan dapat merupakan pendirian suatu kelembagaan. Contohnya adalah Act of Foundation of a Consultative Committee for the International Protection of Nature yang ditandatangani pada tanggal 19 November tahun 1913 di kota Bern, Swiss.

(h) Memorandum of Understanding (MOU). Karena perkembangannya kini kedudukan MOU dapat dianggap setara dengan setiap perjanjian internasional pada umumnya karena adanya hak dan kewajiban yang melekat kepada para pihak penandatangan (UNEP 2007). Contoh MOU diantaranya adalah $M O U$ on the Conservation and Management of Marine Turtles and Their Habitats of the Indian Ocean and South East Asia yang 
ditandatangani di Manila, 23 Juni tahun 2001. Contoh lainnya adalah $M O U$ on ASEAN Sea Turtles Conservation and Protection yang ditandatangani di Bangkok, 12 September tahun 1997.

Masih ada beberapa bentuk lainnya diantaranya Exchange of Notes (EON), Modus Vivendi, Letter of Intent (LOI), Joint Protocol (JP), Framework Convention (FC), Agreed Minutes, Summary Record, Interim Convention, Agreement Supplementary, Letter of Understanding (LOU), Memorandum of Agreement (MOA), Outline Convention, Mutual Agreement, Statute (MAS) dan Additional Protocol, yang kebanyakan merupakan kombinasi dari bentuk yang ada.

Mamalia Paus menjadi komoditi perekonomian yang sangat menguntungkan sejak zaman dahulu. Orang-orang Basque telah memperdagangkan ikan paus di Teluk Biscay (Bay of Biscay) sejak abad ke 11 yang terhenti di abad 16 karena persaingannya dengan orang Inggris dan Belanda (Sands 1993). Populasi mamalia paus semakin hari semakin menipis akibat penangkapan besar-besaran yang mulai terjadi sejak modernisasi di bidang industri perikanan. Mulai dari kapal penangkap kemudian diolah hingga sampai pada produksinya dilakukan dengan teknologi yang efektif dan cepat. Tentu saja secara komersil sangat menguntungkan karena daging, kulit hingga tulang ikan paus sangat laku diperjualbelikan. Hukum internasional berupaya untuk melindungi dan membatasi penangkapan mamalia paus dilakukan sejak tahun 1931 ketika 46 negara menandatangani Convention for the Regulation of Whaling yang berlaku penuh pada tanggal 14 Januari 1936. Menurut Steiner (1988) penangkapan dan pembunuhan terhadap mamalia paus ini tidak terhenti bahkan sampai tahun 1938 sekitar 55.000 paus dari berbagai jenis di Antartika telah dibunuh. Bahkan konvensi ini mengalami kegagalan karena tidak memiliki suatu badan yang mampu mencegah penangkapan secara besarbesaran. Untuk memperbaiki konvensi ini maka atas inisiatif Amerika Serikat ditandatangani International Convention for the Regulation of Whaling di kota Washington pada tanggal 2 Desember 1946. Berdasarkan Pasal 3 Konvensi ini dibentuk International Whaling Commission (IWC) yang dalam pasal 4 menugaskan komisi ini untuk mendorong penelitian dan penyelidikan, mengumpulkan dan menganalisis informasi statistik dan mempublikasikan informasi mengenai mamalia paus dan stok jenis mamalia paus.

Setelah berakhirnya sengketa mengenai masalah jurisdiksi perairan dan perburuan anjing laut di perarian Behring yang dikenal dengan Behring Sea Fur Seals Arbitration 1898 (USA v. Britain (Canada) v. Russia), Amerika Serikat dan Inggris menandatangani perjanjian bilateral tahun 1911 di kota Washington yang dikenal dengan nama Treaty Between Great Britain and the USA for the Preservation and Protection of Fur Seals. Lima bulan kemudian Jepang dan Rusia bergabung untuk memperkuat perjanjian tersebut yang telah direkomendasi oleh keputusan pengadilan arbitrasi dalam Behring Sea Fur Seals. Perjanjian ini dikenal dengan nama Convention for the Preservation and Protection of Fur Seals in the North Pasific yang ditandatangani pada tanggal 7 Juli 1911.

Upaya perlindungan flora dan fauna tidak terlepas dari gerakan konservasi seperti di Inggris tahun 1824 didirikan Society for the Protection of Animals yang kemudian diikuti berbagai organisasi lainnya seperti Commons, Open Spaces and Footpaths Preservation Sociaty tahun 1865, The East Riding Association for the Protection of Sea Birds tahun 1867, yang kemudian mendorong melahirkan berbagai peraturan di Inggris seperti Peraturan mengenai burung laut (1869), peraturan mengenai burung liar (1872). Karena Inggris memiliki koloni yang luas, maka pengaruh gerakan lingkungan hidup ini mulai dirasakan dan berkembang di Australia, Afrika Selatan, India hingga Amerika Serikat. Pada saat itu perburuan terhadap berbagai jenis flora dan fauna masih berlangsung khususnya di belahan Afrika. Maka atas inisiatif Perdana Menteri Inggris pada waktu itu yaitu Lord Salisbury serta usulan pemerintah Jerman untuk mengontrol ekspor gading di Afrika maka pada tahun 1900 di kota London, Inggris ditandatangani Convention for the Preservation of Animals, Birds and Fish in Africa oleh Inggris, Jerman, Perancis, Italia, Portugal dan Belgia (Kongo) (McCormick 1989). Pemahaman common property atau milik umum seperti yang ditegaskan dalam Behring Sea Fur Seals Arbitration 1895 (USA v. Great Britain) yang diputuskan oleh pengadilan arbitrasi dan Icelandic Fisheries Cases (UKv. Iceland v. Germany) 1974 yang diputuskan oleh Mahkamah Internasional menegaskan 
kedudukan flora dan fauna juga harus dilindungi sebagai milik umum.

Pada tanggal 19 Maret 1902, Treaty for the Protection of Birds Useful to Agriculture ditandatangani oleh 14 negara Eropa yang tujuannya untuk melindungi jenis-jenis burung yang berguna bagi pertanian. Dalam appendix konvensi ini terdapat daftar jenis burung yang berguna dan yang mengganggu bagi pertanian. Namun konvensi ini masih memperbolehkan jenis-jenis burung tersebut untuk diburu dalam bulan-bulan tertentu.

Pada tanggal 5-16 Juni 1972 diselenggarakan untuk pertama kalinya suatu konferensi Perserikatan Bangsa-bangsa di bidang lingkungan hidup. Konferensi ini dikenal dengan nama Konferensi PBB mengenai Lingkungan Hidup Manusia (United Nations Conference on Human Environment). Konferensi Stockhlom ini telah mengangkat masalah lingkungan hidup yang pada mulanya hanya dibicarakan di kalangan akademis kini menjadi persoalan politik di mana konsep lingkungan hidup akan menjadi bagian dari pembangunan nasional. Selain itu dari hasil Stockhlom ini, ada beberapa hal yang mengatur upaya perlindungan hewan. Deklarasi Stockhlom yang merupakan bentuk soft law dalam beberapa prinsipnya mengatur upaya perlindungan hewan. Prinsip 2 Deklarasi Stockholm 1972 ingin menegaskan bahwa pentingnya konservasi alam termasuk perlindungan terhadap hewan, menjadi bagian yang tidak terpisahkan dari kebijakan pembangunan nasional suatu negara. Nilai-nilai ekonomis yang ada pada alam dalam pengelolaannya tidak hanya untuk kepentingan pada saat sekarang ini saja tapi juga harus memperhatikan kepentingan generasi mendatang. Karena itu prinsip ini secara tidak langsung telah memperkenalkan konsep penggunaan secara berkelanjutan (sustainable use).

Prinsip 4 Deklarasi ini menuntut adanya tanggungjawab setiap orang untuk menyelamatkan hewan dan habitatnya. Prinsip ini juga menjadi pedoman bagi pengelolaan dan pemanfaatan hewan yang berhubungan dengan adanya perkembangan bioteknologi. Konferensi ini juga memberikan berbagai Rekomendasi berkaitan dengan upaya perlindungan flora dan fauna dimana disebutkan Rekomendasi 29 hingga rekomendasi 50 harus dilaksanakan oleh negara-negara penandatangan sebagai upaya keterlibatannya dalam perlindungan flora dan fauna. Sedangkan badan-badan internasional yang harus melaksanakan rekomendasi ini antara lain Sekretariat Jenderal bekerjasama dengan Badan-badan PBB seperti Food Agricultural Organization (FAO), UNESCO, Komisi Paus Internasional (International Whaling Commission), Man and Biosfire, Program Biologi Internasional, serta pusatpusat dan laboratorium seperti Pusat Pembibitan Tumbuhan Hutan Denmark.

Di kota Washington, pada tanggal 3 Maret 1973 ditandatangani suatu perjanjian internasional yang penting dalam mengendalikan perdagangan tanaman dan satwa langka yaitu Convention on International Trade in Endangered Species of Wild Fauna and Flora (CITES) oleh 27 negara. Konvensi ini bertujuan untuk melindungi spesies langka dari eksploitasi yang berlebihan melalui sistem izin ekspor dan impor. Pada tanggal 15 November 1973 di kota Oslo beberapa negara seperti Kanada, Denmark, Norwegia, Amerika Serikat dan Uni Soviet menandatangani Agreement on Conservation of Polar Bears. Persetujuan ini terdiri atas 10 pasal dan berupaya untuk melindungi beruang kutub sebagai sumber penting di wilayah Artik melalui tindakan konservasi dan pengelolaan.

Namun pada umumnya perjanjian internasional yang berupaya melindungi flora dan fauna pada saat sebelum terbentuknya World Commission on Environment and Development (WCED) masih berparadigma yang cenderung komersil. Misalnya saja CITES 1973 dibentuk tidak untuk melindungi flora dan fauna langka secara murni konservasi akan tetapi masih mempertimbangkan kondisi perdagangan flora dan fauna di tingkat internasional dengan mendasarkan pada daftar spesies yang berupa appendix dan adanya sistem kuota.

Terbentuknya WCED yang telah mengubah paradigma dalam konsep pembangunan yang saat itu hanya mengejar pertumbuhan menjadi pembangunan berkelanjutan (sustainable development). Pembangunan berkelanjutan lebih mementingkan pembangunan tidak hanya peduli pada generasi sekarang tetapi juga generasi mendatang. Maka pada KTT Bumi tahun 1992 melalui Deklarasi Rio 1992 dan United Nations Convention on Biological Diversity 1992 atau Konvensi PBB mengenai Pembangunan Berkelanjutan telah menegaskan 
kembali prinsip-prinsip pembangunan berkelanjutan. Sehingga perjanjian internasional yang dibentuk setelah era Rio 1992 lebih menekankan pentingnya prinsip pembangunan berkelanjutan.

Beberapa perjanjian internasional yang lahir sesudah KTT Bumi 1992 hingga saat ini dalam berbagai bentuk diantaranya: Amendments to the Convention on the Conservation of European Wildlife and Natural Habitats 1995, Amendments to the Schedule to the International Convention for the Regulation of Whaling, Dublin, 1995, Protocol Concerning Specially Protected Areas and Biological Diversity in the Mediterranean 1995, Agreement on the Conservation of African-Eurasian Migratory Waterbirds, 1995, Amendments to Appendices II and III of the Convention on the Conservation of European Wildlife and Natural Habitats 1996, Agreement on the Conservation of Cetaceans of the Black Sea, Mediterranean Sea and Contiguous Atlantic Area 1996, Inter-American Convention for the Protection and Conservation of Sea Turtles 1996, Amendments to Appendices I and II of The Convention on the Conservation of European Wildlife and Natural Habitats 1996, Additions to Appendix I and Appendix II of the Convention on the Conservation of Migratory Species of Wild Animals adopted by the Fifth Conference of the Parties, 1997 Amendments to the International Plant Protection Convention 1997, Cartagena Protocol on Biosafety to the convention on biological diversity 2000, Second Amendment to the Agreement on the Conservation of Bats in Europe 2000, Convention on the Conservation and Management of Highly Migratory Fish Stocks in The Western and Central Pacific Ocean 2000, Amendments to the Agreement for the Establishment of a Commission for Controlling the Desert Locust in Southwest Asia 2000, Convention on the Conservation and Management of Fishery Resources in the South-East Atlantic Ocean 2001, Agreement on the Conservation of Albatrosses and Petrels 2001, International Treaty on Plant Genetic Resources for Food and Agriculture 2001, Treaty on the Conservation and Sustainable Development of the Forest Ecosystems of Central Africa 2005, Agreement on the Establishment of the ASEAN Centre for Biodiversity (ACB) 2005, International Tropical Timber Agreement 2006, Southern Indian Ocean Fisheries
Agreement 2006, Agreement on the Conservation of Gorillas and their Habitats (Gorilla Agreement) 2007, Amendment of Annexes 2 and 3 and Table 1 to the Agreement on the Conservation of African-Eurasian Migratory Waterbirds 2008, Agreement on Port State Measures to Prevent, Deter and Eliminate Illegal, Unreported and Unregulated Fishing 2009, Nagoya-Kuala Lumpur Supplementary Protocol on Liability and Redress to the Cartagena Protocol on Biosafety 2010, Nagoya Protocol on Access to Genetic Resources and the Fair and Equitable Sharing of the Benefits Arising from their Utilization to the Convention on Biological Diversity 2010, Convention on the Conservation and Management of High Seas Fisheries Resources in the North Pacific Ocean 2012, Amendment to Annex 1 of the Agreement on the Conservation of Albatrosses and Petrels 2012, Agreement on the Establishment of the Coordinating Council on Plant Quarantine States 2012, Amendments to the Schedule of the International Convention for the Regulation of Whaling 2014 dan Amendment to Annex lof the Agreement on the Conservation of Albatrosses and Petrels tahun 2014.

Perjanjian-perjanjian internasional tersebut diatas berupaya untuk melindungi, melestarikan, membatasi hingga melarang pemanfaatan sumber daya alam seperti flora dan fauna baik di darat, laut maupun udara agar tetap lestari. Selain itu perjanjian-perjanjian internasional tersebut pada umumnya telah menekankan paradigma baru yaitu memasukan konsep pembangunan berkelanjutan dengan harapan sumber daya alam berupa flora dan fauna yang dimanfaatkan generasi sekarang tetap dapat juga dimanfaatkan dan dilestarikan bagi generasi mendatang.

\section{METODE PENELITIAN}

Metode yang digunakan dalam studi ini adalah penelitian deskriptif analitis dengan pendekatan historical normative documents. Penelitian deskriptif diharapkan dapat menggambarkan kondisi perjanjian internasional terkait perlindungan flora dan fauna. Selain itu juga digambarkan bagaimana peran perjanjian internasional tersebut dalam kerangka perlindungan flora dan fauna. Pendekatan melalui analisis dokumen perjanjian internasional yang bersifat normatif yang mengatur ketentuan yang berhubungan 
dengan perlindungan flora dan fauna yang diantaranya dengan menginventarisasikan, mengidentitifikasi, menyusun keterkaitan dan menganalisis serta diharapkan dapat menghasilkan studi yang sesuai dengan tujuan penelitian.

Data diambil dari berbagai perjanjian internasional terkait dengan perlindungan flora dan fauna yang kemudian dipilih sesuai dengan tujuan penelitian. Berbagai perjanjian internasional tersebut kemudian diidentifikasi dan dipilih ketentuan berdasarkan pada tujuan penelitian yaitu ketentuan yang terkait dengan perlindungan flora dan fauna.

Dari data yang diperoleh baik data hukum primer yang berupa daftar perjanjian internasional dan data hukum sekunder berupa dokumen lainnya yang mendukung penjelasan mengenai data hukum primer, maka dapat dianalisis melalui kajian normatif. Dari hasil analisis ini maka dapat ditarik suatu kesimpulan dari hasil penelitian.

\section{HASIL DAN PEMBAHASAN}

\subsection{Gambaran Umum}

Seperti telah dijelaskan diatas telah banyak perjanjian internasional yang berkembang di bidang perlindungan flora dan fauna. Umumnya perjanjian internasional tersebut dapat digambarkan pada tabel $1 \mathrm{di}$ bawah ini.

Peneliti mencatat, dalam kurun waktu 1876 hingga 2006 lima perjanjian internasional yang terkait dengan perlindungan flora dan fauna berbentuk hard law. Treaty concerning the Jan Mayen Seal Fishery tercatat sebagai perjanjian internasional yang cukup tua yang ditandatangani pada tahun 1876. Sedangkan perjanjian internasional yang berbentuk soft law, penelitian menunjukkan adanya empat perjanjian internasional yang terkait dengan perlindungan flora dan fauna dalam kurun waktu 1978-1982 terdapat. Dengan demikian dari sembilan perjanjian internasional yang terkait dengan flora dan fauna dalam kurun waktu 1876 hingga 2006 ada yang berbentuk soft law maupun hard law.
Tabel 1. Gambaran Kategorisasi Beberapa Perjanjian Internasional Terkait Perlindungan Flora Dan Fauna yang Bersifat Hard Law Maupun Soft Law

\begin{tabular}{|c|c|c|c|}
\hline No & $\begin{array}{l}\text { Bentuk } \\
\text { Perjanjlan } \\
\text { Internasional }\end{array}$ & Nama Perjan|lan Internasional & $\begin{array}{l}\text { Tahun } \\
\text { Penanda- } \\
\text { tanganan }\end{array}$ \\
\hline A & Hard Law & & \\
\hline \multirow[t]{2}{*}{1.} & Treaty & $\begin{array}{l}\text { Treaty Conceming the Jan Mayen } \\
\text { Seal Fishery }\end{array}$ & 1876 \\
\hline & & $\begin{array}{l}\text { Intemational Treaty on Plant Genettc } \\
\text { Resources for Food and Agricuture. }\end{array}$ & 2001 \\
\hline \multirow[t]{2}{*}{2.} & Convention & $\begin{array}{l}\text { Affican Convention on the } \\
\text { Conservation of Nature and Natural } \\
\text { Resources }\end{array}$ & 2003 \\
\hline & & $\begin{array}{l}\text { Inter-American Convention for the } \\
\text { Protection and Conservation of Sea } \\
\text { Turtles }\end{array}$ & 1996 \\
\hline \multirow[t]{2}{*}{3.} & Agreement & $\begin{array}{l}\text { Agreement on the Conservation of } \\
\text { GorlWas and thelr Habitats }\end{array}$ & 2007 \\
\hline & & $\begin{array}{l}\text { Plant Protectlon Agreement for the } \\
\text { Asla and Pacmic Reglon }\end{array}$ & 1955 \\
\hline \multirow[t]{2}{*}{4.} & Protocol & $\begin{array}{l}\text { Cartagena Protocol on Blosafety to } \\
\text { the Convention on Blological } \\
\text { Diversity }\end{array}$ & 2000 \\
\hline & & $\begin{array}{l}\text { Protocol Conceming Speclally } \\
\text { Protected Areas and Willie to the } \\
\text { Convention for the Protection and } \\
\text { Development of the Marine } \\
\text { Environment of the wider Cariboean } \\
\text { Region }\end{array}$ & 1990 \\
\hline \multirow[t]{3}{*}{5.} & MOU & $\begin{array}{l}\text { Memorandum of Understanding } \\
\text { concerning Conservation Measures } \\
\text { for the Eastem Atlantic Populations } \\
\text { of the Mediterranean Monk Seal } \\
\text { (Monachus monachus) }\end{array}$ & 2007 \\
\hline & & $\begin{array}{l}\text { Memorandum of Understanding } \\
\text { concerning }\end{array}$ & 2006 \\
\hline & & $\begin{array}{l}\text { Restoration and Sustainable Use of } \\
\text { the Salga Antelope (Salga tatarica } \\
\text { tatarica) }\end{array}$ & \\
\hline B & Soft Law & & \\
\hline 1. & Declaration & $\begin{array}{l}\text { Universal Declarations of the Rights } \\
\text { of Animal }\end{array}$ & 1978 \\
\hline 2. & Action Plan & $\begin{array}{l}\text { Environmental Cooperation Action } \\
\text { Plan between the Govemment of } \\
\text { Canada and the Govemment of the } \\
\text { People's Reoublic of China }\end{array}$ & 1999 \\
\hline 3. & Programme & $\begin{array}{l}\text { Agreement on the Intemational } \\
\text { Doliphin Conservation Programme }\end{array}$ & 1998 \\
\hline 4 & Charter. & Worid Charter for Nature & 1982 \\
\hline
\end{tabular}

Sumber: Hasil Penelitian (2016)

Dari berbagai bentuk perjanjian internasional yang berhubungan dengan flora dan fauna tersebut, tetap berpegang pada ketentuan yang diatur dalam Vienna Convention on the Law of Treaties 1969 di mana konvensi ini membebaskan para pihak untuk membentuk dan mengatur ketentuan yang sesuai dengan kesepakatan para pihak.

\subsection{Perjanjian Internasional Global yang Berhubungan dengan Perlindungan Flora dan Fauna}

Ada beberapa perjanjian internasional yang berhubungan dengan flora dan fauna yang secara global telah disepakati. Perjanjian internasional yang termasuk kategori tersebut dapat dilihat dalam tabel 2 berikut ini.

Peneliti mencatat 17 (tujuh belas) perjanjian internasional yang berhubungan 
dengan perlindungan flora dan fauna yang disepakati dalam kurun waktu 1946 hingga 2012 bersifat global.

Tabel 2. Beberapa Perjanjian Internasional yang Berhubungan dengan Perlindungan Flora dan Fauna yang Disepakati di Tingkat Global

\begin{tabular}{|c|c|c|c|}
\hline No & Nama Perjanjian & $\begin{array}{l}\text { Tempat } \\
\text { Penanda- } \\
\text { Tanganan }\end{array}$ & $\begin{array}{l}\text { Waktu } \\
\text { Penanda- } \\
\text { Tanganan }\end{array}$ \\
\hline 1. & $\begin{array}{l}\text { International Convention for the Regulation } \\
\text { of Whaling }\end{array}$ & Washington & 1946 \\
\hline 2. & $\begin{array}{l}\text { Convention on International Trade in } \\
\text { Endangered Species of Wild Fauna and } \\
\text { Flora }\end{array}$ & Washington & 1973 \\
\hline 3. & $\begin{array}{l}\text { Convention on the Conservation of } \\
\text { Migrator Species of Wild Animals. }\end{array}$ & Bonn & 1979 \\
\hline 4. & $\begin{array}{l}\text { Convention on Fishing and Conservation of } \\
\text { the Living Resources of the High Seas }\end{array}$ & Geneva & 1958 \\
\hline 5. & $\begin{array}{l}\text { Convention on Wettands of Intemational } \\
\text { Importance, Especially as Waterfowi } \\
\text { Habitats }\end{array}$ & Ramsar & 1971 \\
\hline 6. & $\begin{array}{l}\text { Convention for the Conservation of Antartic } \\
\text { Seals }\end{array}$ & London & 1972 \\
\hline 7. & $\begin{array}{l}\text { Convention on the Conservation of } \\
\text { Migratory Species of Wild Animals }\end{array}$ & Bonn & 1979 \\
\hline 8. & $\begin{array}{l}\text { United Nations Convention on Biological } \\
\text { Diversity }\end{array}$ & Rio De Janerio & 1892 \\
\hline$\frac{8}{10 .}$ & $\begin{array}{l}\text { International Tropical Timber Agreement } \\
\text { International Treaty on Plant Genetic } \\
\text { Resources for Food and Agriculture }\end{array}$ & $\begin{array}{l}\text { Jenewa } \\
\text { Roma }\end{array}$ & $\begin{array}{l}1894 \\
2001\end{array}$ \\
\hline 11. & $\begin{array}{l}\text { Agreement on the Conservation of } \\
\text { Albatrosses and Petrels }\end{array}$ & Canbera & 2001 \\
\hline 12. & $\begin{array}{l}\text { International Olive OII and Table Olive } \\
\text { Agreement }\end{array}$ & Jenewa & 2005 \\
\hline 13. & $\begin{array}{l}\text { Agreement on the Conservation of Gorillas } \\
\text { and their Habitats }\end{array}$ & Paris & 2007 \\
\hline 14. & $\begin{array}{l}\text { Agreement on Port State Measures to } \\
\text { Prevent, Deter and Eliminate Illegal, } \\
\text { Unreported and Unregulated Fishing }\end{array}$ & Roma & 2009 \\
\hline 15. & $\begin{array}{l}\text { Nagoya Protocol on Access to Genetic } \\
\text { Resources and the Fair and Equitable } \\
\text { Sharing of the Benefits Arising from their } \\
\text { Utilization to the Convention on Biological } \\
\text { Diversity }\end{array}$ & Nagoya & 2010 \\
\hline 16. & $\begin{array}{l}\text { Convention on the Conservation and } \\
\text { Management of High Seas Fisheries } \\
\text { Resources in the North Pacific Ocean }\end{array}$ & Tokyo & 2012 \\
\hline 17. & $\begin{array}{l}\text { Agreement an the Establishment of the } \\
\text { Coordinating Council on Plant Quarantine } \\
\text { States }\end{array}$ & Roma & 2012 \\
\hline
\end{tabular}

Sumber: Hasil Penelitian (2016)

Keragaman perjanjian internasional yang disepakati oleh para pihak dimana upaya perlindungan flora seperti jenis tanaman, bunga maupun sumberdaya genetik tanaman lainnya serta fauna seperti fauna yang hidup di darat, lautan dan yang terbang di udara dimaksudkan agar flora dan fauna tersebut tetap lestari. Namun demikian perkembangan penting dalam perlindungan flora dan fauna adalah kesepakatan yang dicapai dalam KTT Rio 1992 yaitu Konvensi Perserikatan Bangsa-Bangsa mengenai Keanekaragaman Hayati (United Nations Convention on Biological Diversity) tahun 1992. Konvensi ini menjadi kesepakatan penting karena mengatur secara komprehensif baik keanekaragaman gen, ekosistem maupun spesies.

\subsection{Perjanjian Internasional Regional yang Berhubungan dengan Perlindungan Flora dan Fauna}

Ada beberapa perjanjian internasional yang berhubungan dengan flora dan fauna yang secara regional telah disepakati. Perjanjian internasional tersebut dapat dilihat dalam tabel 3 berikut ini.

Peneliti mencatat tujuh belas (17) perjanjian internasional yang berhubungan dengan perlindungan flora dan fauna yang disepakati di tingkat regional dalam kurun waktu 1950-2003.

Tabel 3. Beberapa Perjanjian Internasional yang berhubungan dengan Perlindungan Flora dan Fauna yang Disepakati di Tingkat Regional

\begin{tabular}{|c|c|c|c|}
\hline No & Nama Perjanjian & $\begin{array}{l}\text { Tempat } \\
\text { Penanda- } \\
\text { Tanganan } \\
\end{array}$ & $\begin{array}{l}\text { Tahun } \\
\text { Penanda- } \\
\text { Tanganan } \\
\end{array}$ \\
\hline 1. & $\begin{array}{l}\text { International Convention for the } \\
\text { Protection of Birds }\end{array}$ & Paris & 1950 \\
\hline 2. & $\begin{array}{l}\text { Agreement Conceming Measures for } \\
\text { the Protection of the Stocks of Deep- } \\
\text { Sea Prawns, European Lobsters, } \\
\text { Norway Lobsters and Crabs }\end{array}$ & Oslo & 1852 \\
\hline 3. & $\begin{array}{l}\text { European Convention for the Protection } \\
\text { of Animals Kept for Farminq Purposes }\end{array}$ & Strasbourg & 1976 \\
\hline 4. & $\begin{array}{l}\text { Aqreement Between Norway and the } \\
\text { USSR on Measures for Regulating the } \\
\text { Chatch and Conserving Stocks of seals } \\
\text { in the North Easterm Part of the Atlantic } \\
\text { Ocean }\end{array}$ & Oslo & 1957 \\
\hline 5. & $\begin{array}{l}\text { Convention Conceming Fishing in the } \\
\text { Waters of the Danube }\end{array}$ & Bucharest & 1958 \\
\hline 6. & $\begin{array}{l}\text { Convention on the Conservation of } \\
\text { European Wildlife and Natural Habitats }\end{array}$ & Berne & 1979 \\
\hline 7. & $\begin{array}{l}\text { European Convention for the Protection } \\
\text { of Animals Used for Slaughter }\end{array}$ & Strasbourg & 1979 \\
\hline 8. & $\begin{array}{l}\text { Convention for the Conservation of } \\
\text { Salmon in the North Atlantic Ocean }\end{array}$ & Reykjavik & 1982 \\
\hline 8. & $\begin{array}{l}\text { ASEAN Aqreement on the Conservation } \\
\text { of Nature and Natural Resources }\end{array}$ & Kualalumpur & 1985 \\
\hline 10. & $\begin{array}{l}\text { European Convention for the Protection } \\
\text { of Pet Animals }\end{array}$ & Strasbourg & 1987 \\
\hline 11. & $\begin{array}{l}\text { Convention for the Prohibition of Fishing } \\
\text { with Long Driftnets in the South Pasific }\end{array}$ & Wellington & 1989 \\
\hline 12. & $\begin{array}{l}\text { Aareement on the Conservation of Seals } \\
\text { in the Wadden Sea }\end{array}$ & Bonn & 1990 \\
\hline 13. & $\begin{array}{l}\text { Aqreement on the Conservation of } \\
\text { African-Eurasian Migratory Waterbirds }\end{array}$ & Den Haag & 1995 \\
\hline 14. & $\begin{array}{l}\text { Aqreement on the Conservation of } \\
\text { Cetaceans of the Black Sea, } \\
\text { Mediterranean Sea and Contiguous } \\
\text { Atlantic Area }\end{array}$ & Monaco & 1996 \\
\hline 15. & $\begin{array}{l}\text { International Agreement on the creation } \\
\text { of a marine mamma/ sanctuary in the } \\
\text { Mediterranean }\end{array}$ & Roma & $199 \theta$ \\
\hline 16. & Protocol on Forestry & Luanda & 2002 \\
\hline 17 & $\begin{array}{l}\text { African Convention on the Conservation } \\
\text { of Nature and Natural Resources }\end{array}$ & Maputo & 2003 \\
\hline
\end{tabular}

Sumber: Hasil Penelitian (2016)

Keberadaan perjanjian internasional mengenai perlindungan flora dan fauna di tingkat regional menjadi sangat penting dikarenakan ada spesies tertentu yang hanya ditemukan di regional tersebut tetapi tidak ditemukan di regional lainnya. Selain itu keberadaan perjanjian internasional regional tersebut akan meningkatkan juga jumlah spesies yang harus dilindungi oleh negaranegara di tingkat regional. 


\subsection{Perjanjian Internasional yang Berhubungan dengan Perlindungan Flora dan Fauna Terkait dengan Sistem Perdagangan Internasional dan Regional}

Ada beberapa perjanjian internasional yang berhubungan dengan flora dan fauna yang terkait dengan system perdagangan internasional. Perjanjian internasional tersebut dapat dilihat dalam tabel 4 berikut ini.

Peneliti mencatat tujuh belas (17) perjanjian internasional yang berhubungan dengan perlindungan flora dan fauna yang terkait dengan sistem perdagangan internasional dan regional.

Tabel 4. Beberapa Perjanjian Internasional yang berhubungan dengan Perlindungan Flora dan Fauna yang Terkait dengan Sistem Perdagangan Internasional dan Regional

\begin{tabular}{|c|c|c|c|}
\hline No & Nama Perjanjian & $\begin{array}{l}\text { Tempat } \\
\text { Penanda- } \\
\text { Tanganan }\end{array}$ & $\begin{array}{l}\text { Tahun } \\
\text { Penanda- } \\
\text { Tanganan } \\
\end{array}$ \\
\hline 1. & $\begin{array}{l}\text { International Convention for the } \\
\text { Protection of Birds }\end{array}$ & Paris & 1950 \\
\hline 2. & $\begin{array}{l}\text { Agreement Conceming Measures for } \\
\text { the Protection of the Stocks of Deep- } \\
\text { Sea Prawns, European Lobsters, } \\
\text { Norway Lobsters and Crabs }\end{array}$ & Oslo & 1952 \\
\hline 3. & $\begin{array}{l}\text { European Convention for the Protection } \\
\text { of Animals Kept for Farminq Purposes }\end{array}$ & Strasbourg & 1976 \\
\hline 4. & $\begin{array}{l}\text { Aqreement Between Norway and the } \\
\text { USSR on Measures for Regulating the } \\
\text { Chatch and Conserving Stocks of seals } \\
\text { in the North Eastem Part of the Atlantic } \\
\text { Ocean }\end{array}$ & Oslo & 1957 \\
\hline 5. & $\begin{array}{l}\text { Convention Conceming Fishing in the } \\
\text { Waters of the Danube }\end{array}$ & Bucharest & 1958 \\
\hline 6. & $\begin{array}{l}\text { Convention on the Conservation of } \\
\text { European Wild life and Natural Habitats }\end{array}$ & Berne & 1979 \\
\hline 7. & $\begin{array}{l}\text { European Convention for the Protection } \\
\text { of Animals Used for Slauqhter }\end{array}$ & Strasbourg & 1979 \\
\hline 8. & $\begin{array}{l}\text { Convention for the Conservation of } \\
\text { Salmon in the North Atlantic Ocean }\end{array}$ & Reykjavik & 1982 \\
\hline 9. & $\begin{array}{l}\text { ASEAN Aqreement on the Conservation } \\
\text { of Nature and Natural Resources }\end{array}$ & Kualalumpur & 1985 \\
\hline 10. & $\begin{array}{l}\text { European Convention for the Protection } \\
\text { of Pet Animals }\end{array}$ & Strasbourg & 1987 \\
\hline 11. & $\begin{array}{l}\text { Convention for the Prohibition of Fishing } \\
\text { with Long Driftnets in the South Pasific }\end{array}$ & Wellington & 1989 \\
\hline 12. & $\begin{array}{l}\text { Aqreement on the Conservation of Seals } \\
\text { in the Wadden Sea }\end{array}$ & Bonn & 1990 \\
\hline 13. & $\begin{array}{l}\text { Aqreement on the Conservation of } \\
\text { African-Eurasian Migratory Waterbirds }\end{array}$ & Den Haag & 1995 \\
\hline 14. & $\begin{array}{l}\text { Aqreement on the Conservation of } \\
\text { Cetaceans of the Black Sea, } \\
\text { Mediterranean Sea and Contiguous } \\
\text { Atlantic Area }\end{array}$ & Monaco & 1996 \\
\hline 15. & $\begin{array}{l}\text { International Agreement on the creation } \\
\text { of a manine mammal sanctuary in the } \\
\text { Mediterranean }\end{array}$ & Roma & 1999 \\
\hline $\begin{array}{l}16 . \\
17 .\end{array}$ & $\begin{array}{l}\text { Protocol on Forestry } \\
\text { African Convention on the Conservation } \\
\text { of Nature and Natural Resources }\end{array}$ & $\begin{array}{l}\text { Luanda } \\
\text { Maputo }\end{array}$ & $\begin{array}{l}2002 \\
2003\end{array}$ \\
\hline
\end{tabular}

Sumber: Hasil penelitian (2016)

Sistem perdagangan internasional maupun regional saat ini telah berkembang dengan sistem yang lebih transparan. Perdagangan flora dan fauna langka tanpa memiliki izin dan bersifat illegal masih sering terjadi. Berbagai upaya pembatasan atas perdagangan flora dan fauna juga terus dilakukan baik di tingkat global maupun regional.

\subsection{Perjanjian Internasional yang Berhubungan dengan Perlindungan Flora dan Fauna Terkait dengan Konservasi}

Ada beberapa perjanjian internasional yang berhubungan dengan flora dan fauna yang berupaya untuk dilakukan perlindungan dan pelestarian. Perjanjian internasional tersebut dapat dilihat dalam tabel 5 di bawah ini.

Peneliti mencatat setidaknya terdapat dua puluh tiga (23) perjanjian internasional yang berhubungan dengan perlindungan flora dan fauna yang terkait dengan upaya konservasi dalam kurun waktu 1931-2012).

Tabel 5 Beberapa Perjanjian Internasional yang berhubungan dengan Perlindungan Flora dan Fauna yang Terkait dengan Upaya Konservasi

\begin{tabular}{|c|c|c|c|}
\hline No & Nama Perjanjan & Perlindungan & Tahun \\
\hline 1. & $\begin{array}{l}\text { Interim Convention on Conservation of } \\
\text { North Pasific Fur seals }\end{array}$ & $\begin{array}{l}\text { Perlindungan } \\
\text { Aniing laut }\end{array}$ & 1931 \\
\hline 2. & $\begin{array}{l}\text { Acreement Between Norway and } \\
\text { Finland Regardina New Fishing } \\
\text { Requdations of the Fishinq Area of the } \\
\text { Tana River }\end{array}$ & $\begin{array}{l}\text { Perlindungan } \\
\text { ienis ikan di } \\
\text { Sungai tana }\end{array}$ & 1960 \\
\hline 3. & $\begin{array}{l}\text { Agreement on the Protection of the } \\
\text { Saimon in the Baltic Sea }\end{array}$ & $\begin{array}{l}\text { Perlindungan } \\
\text { ikan salmon }\end{array}$ & 1962 \\
\hline 4. & $\begin{array}{l}\text { Agreement Between Canada and } \\
\text { Norway on Sealing and the } \\
\text { Conservation of the Seal Stock in the } \\
\text { North-West Atlantic }\end{array}$ & $\begin{array}{l}\text { Perlindungan } \\
\text { Anjing Laut }\end{array}$ & 1971 \\
\hline 5. & $\begin{array}{l}\text { Convention Between Japan and the } \\
\text { USA for the Protection of Miqratory } \\
\text { Birds in Danger of Exdinction and Their } \\
\text { Environment }\end{array}$ & $\begin{array}{l}\text { Perlindungan } \\
\text { Burung Migran }\end{array}$ & 1972 \\
\hline 6. & $\begin{array}{l}\text { European Convention for the } \\
\text { Protection of Animals Kept for Farming } \\
\text { Puposes }\end{array}$ & $\begin{array}{l}\text { Perlindungan } \\
\text { satwa } \\
\text { peliharaan untuk }\end{array}$ & 1978 \\
\hline 7. & Convention on the Conservation of & $\begin{array}{l}\text { Perlindungan } \\
\text { Spesies Migran }\end{array}$ & 1979 \\
\hline 8. & $\begin{array}{l}\text { Convention on the Conservation of } \\
\text { European Wilalife and Natural Habitats }\end{array}$ & $\begin{array}{l}\text { Berbagai jenis } \\
\text { tanaman, satwa } \\
\text { dan ekosistem } \\
\text { sebagai habitat }\end{array}$ & \\
\hline 9. & $\begin{array}{l}\text { Comvention on the Conservation of } \\
\text { European Wilolife and Natural Habitats }\end{array}$ & $\begin{array}{l}\text { Perlindungan } \\
\text { hidupan liar }\end{array}$ & 1979 \\
\hline 10. & $\begin{array}{l}\text { European Convention for the } \\
\text { Protection of Animals Used for } \\
\text { Slaughter }\end{array}$ & $\begin{array}{l}\text { Perlindungan } \\
\text { hewan dari } \\
\text { penyembelihan }\end{array}$ & 1979 \\
\hline 11 & $\begin{array}{l}\text { Comvention for the Conservation of } \\
\text { Saimon in the North Atlantic Ocean }\end{array}$ & $\begin{array}{l}\text { Perlindungan } \\
\text { ikan salmon }\end{array}$ & 1982 \\
\hline 12 & $\begin{array}{l}\text { European Convention for the } \\
\text { Protection of Pet Animals }\end{array}$ & $\begin{array}{l}\text { Perlindungan } \\
\text { hewan } \\
\text { peliharaan }\end{array}$ & 1987 \\
\hline 13 & $\begin{array}{l}\text { Convention for the Prohibition of } \\
\text { Fishing with Long Driftnets in the South } \\
\text { Pasific }\end{array}$ & $\begin{array}{l}\text { Perlindungan } \\
\text { ikan dan } \\
\text { mamalia laut } \\
\text { dari } \\
\text { penangkapan } \\
\text { yang } \\
\text { menoqunakan } \\
\text { jaring yang luas }\end{array}$ & 1889 \\
\hline 14 & $\begin{array}{l}\text { Agreement on The Conservation of } \\
\text { African-Eurasian Migratory Waterbirds }\end{array}$ & $\begin{array}{l}\text { Perlindungan } \\
\text { berbagai jenis } \\
\text { unggas }\end{array}$ & 1985 \\
\hline
\end{tabular}




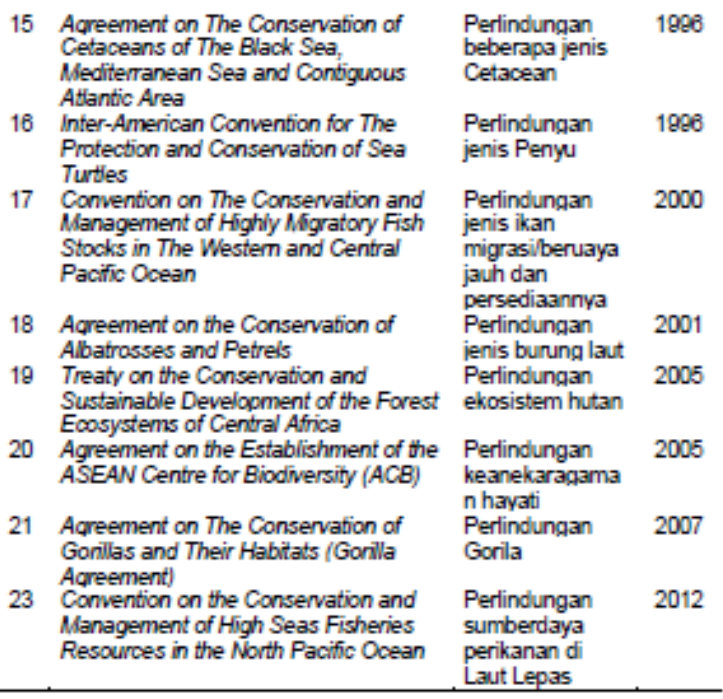

Sumber: Hasil Penelitian (2016)

Perlindungan flora dan fauna menjadi penting saat ini, apalagi untuk jenis tertentu menjadi semakin kritis karena diburu dan diperdagangkan secara illegal. Diperlukan tindakan tegas melalui perangkat hukum internasional dan sebagai dasar hukumnya salah satunya adalah melalui ketentuanketentuan dalam perjanjian internasional. Namun perjanjian internasional yang berfokus pada perlindungan flora dan fauna sangat sedikit dan lebih banyak yang bersifat komersil.

\section{PENUTUP}

Adapun kesimpulan dalam penelitian ini adalah sebagai berikut: (a) sudah banyak perjanjian internasional yang mengatur perlindungan flora dan fauna. (b) perjanjian interasional yang mengatur perlindungan flora dan fauna ada yang bersifat komersil ada pula yang non komersil. (c) Perjanjian internasional yang disepakati ternyata memiliki berbagai bentuk maupun sifat mengikatnya.

Adapun rekomendasi dalam penelitian ini adalah sebagai berikut: (a) perlu dilakukan studi yang lebih mendalam terutama menyangkut ketentuan-ketentuan yang ada dalam perjanjian internasional terkait perlindungan flora dan fauna. (b) perlu dilakukan kajian yang lebih operasional dengan melihat kenyataan-kenyataan terutama implementasi di tingkat nasional khususnya Indonesia. (c) kajian ini akan memberikan informasi bagi pihak-pihak yang berkepentingan untuk mengembangkan lebih lanjut penelitian ini terutama penelitian di bidang flora dan fauna.

\section{DAFTAR PUSTAKA}

Agusman, Damos Dumoli. 2010. Hukum Perjanjian Internasional Kajian Teori Dan Praktek Di Indonesia. Bandung: Refika Aditama.

Andersen, Steiner. 1988. "Science and Politics in the International Management of Whales". Marine Policy 99,101.

Bernie, Patricia W \& Alan E Boyle. 1992. International Law and the Environment. Oxford University Press; London.

Clarke, C.M. 2014. Nepenthes rigidifolia. The IUCN Red List of Threatened Species 2014: e.T49002226A49009927. Diakses 06 Januari 2020. http://dx.doi.org/10.2305/IUCN.UK.201 4-1.RLTS.T49002226A49009927.en.

Clarke, C.M. 2018. Nepenthes fusca (errata version published in 2019). The IUCN Red List of Threatened Species 2018: e.T40109A143967109. Diakses 06 Januari 2020. http://dx.doi.org/10.2305/IUCN.UK.201 8-1.RLTS.T40109A143967109.en.

De Klemm, Cyrille. 1993. Biological Diversity Conservation and the Law: Legal Mechanism for Conserving Species and Ecosystem. IUCN Environmental Law and Policy Law Paper No. 29, IUCN; Glen.

IUCN. 2019. The IUCN Red List of Threatened Species. Version 2019-3. Diakses $\quad 10 \quad$ December 2019. http://www.iucnredlist.org.

Kiss, Alexander C. 1976. Survey of Current Developments in International Environmental Law. FUST-IUCN; Gland.

Kusumaatmadja, Mochtar. 1976. Pengantar Hukum Internasional. Binacipta; Bandung.

Mauna, Boer. 2008. Hukum Internasional: Pengertian, Peranan dan Fungsi dalam Era Dinamika Global. Alumni; Bandung.

McCormick, John. 1989. The Global Environment Movement. Belhaven Press; London. 
Parthiana, I Wayan. 2002. Hukum Perjanjian Internasional Bagian 1. Mandar Maju; Bandung.

Pramudianto, Andreas. 2004. "Perlindungan Satwa: Studi Awal Perjanjian Internasional."

https://www.researchgate.net/publication 1233986877 Perlindungan Satwa Studi Awal_Perjanjian_Internasional

Pramudianto, Andreas. 2014. Hukum Perjanjian Lingkungan Internasional. Setara Press; Malang.

Pratomo, Eddy. 2011. Hukum Perjanjian Internasional Pengertian, Status Hukum Dan Ratifikasi (Praktik Indonesia Dan Beberapa Negara Lain). Bandung: PT Alumni.

Pratomo, Edy. 2011. Hukum Perjanjian Internasional: Pengertian, Status Hukum dan Ratifikasi. Alumni; Bandung.

Sands, Phillipe. 1993. Greening International Law, Earthscan Publication Ltd; London.

Starke, JG. 2010. Pengantar Hukum Internasional Jilid II. Edisi ke 10. Penerbit Sinar Grafika; Jakarta.

Suryokusumo, Sumaryo. 2008. Hukum Perjanjian Internasional. Tatanusa; Jakarta.

UNEP. 2007. Multilateral Environmental Agreement Negotiator's Handbook. Nairobi: UNEP.

United Nations. 1973. "Report of the United Nations Conference on the Human Environment, Stockholm, 5-16 June 1972." A/CONF.48/14/Rev.1. United Nations.

—. 1992. The Rio Declaration on Environment and Development. A/CONF.151/26 (Vol. I).

World Commission on Environment and Development. 1987. Our Common Future. Oxford; New York: Oxford University Press. 